Magyar Honvédség Egészségügyi Központ, 1-es telephely, Diabetológiai Szakrendelés, Budapest, ${ }^{1}$ Szent János Kórház, II. Belgyógyászat-Diabetológia, az SE Oktató- és gyakorlóosztálya, Budapest, ${ }^{2}$ Miskolci Egyetem Egészségügyi Kar, Elméleti Egészségtudományi Intézet ${ }^{3}$

\title{
A gestatiós diabetes kórismézésének és ellátásának újabb szempontjai
}

\author{
Baranyi Éva dr., ${ }^{(1)}$ Winkler Gábor dr. ${ }^{(2,3)}$
}

\begin{abstract}
Osszefoglalás,
A gestatiós diabetes (GDM) gyakorisága hazánkban az ezredforduló táján mintegy megháromszorozódott, igy jelentősen növekedett azon személyek köre, akik esetében a számolnunk kell az állapot aktuális, illetve hosszabb távú veszélyeztetö hatásával. Anyai oldalról a hypertonia-preeclampsia, koraszülés, szülési trauma és császármetszés elöfordulása, magzati vonatkozásban pedig a terhességi korra számított nagy súlyú magzatok világrajövetele, az újszülöttkori hypoglykaemia és a respiratorikus distress szindróma kialakulása válhat gyakoribbá. GDM után jelentösen megnö az anyai cardiovascularis rizikó és a késöbbi diabetes megjelenésének valószinüsége, mig GDM-es anyák gyermekeinél gyakoribb a fiatalkori elhizás, a csökkent glukóztolerancia és a manifeszt diabetes megjelenése. Fontos feladat tehát a GDM kialakulásának csökkentése, esetleges megelözése, de legalábbis minél korábbi felismerése, optimális kezelése és a veszélyeztetettek utánkövetése. Munkánk e lehetöségeket tekinti át az újabb irodalmi adatok és legfrissebb irányelvek, ajánlások figyelembevételével.

Kulcsszavak: gestatiós diabetes, megelözés, kórismézés, kezelés, utánkövetés
\end{abstract}

\section{Recent aspects of diagnosis and care of gestational diabetes mellitus}

Summary: The prevalence of gestational diabetes mellitus (GDM) around the second millennium increased in nearly threefold manner in Hungary, so there is a significant growth in the number of people where the actual and long-term threatening effect of this metabolic disturbance has to be taken into account. From the maternal side the occurrence of hypertension-preeclampsia, preterminal birth, the number of caesarean sections and birth traumas, while in fetal aspect the birth of babies large for gestational age, the number of newborn hypoglycemias, as well as the appearance of respiratory distress syndrome may increase. After GDM rises the maternal cardiovascular risk as well as the probability of a later diabetes mellitus, while at children born from mothers with GDM a greater frequency of juvenile obesity and impairment of the glucose tolerance can be calculated. So, the prevention or at least the reduction, the possible earliest recognition, as well as the optimal treatment of GDM, the careful long-term follow-up of mothers with GDM and children born from these pregnancies is of great importance. These opportunities in the light of latest literary data and guidelines are overviewed in the article.

Keywords: gestational diabetes, prevention, diagnosis, treatment, follow-up

Rövidítések

ACOG: Amerikai Nőgyógyász Társaság (American College of Obstetricians and Gynecologists); EBCOG: Európai Nőgyógyász Társaság (European Board and College of Obstetrics and Gynecology); FIGO: Nemzetközi Szülészeti és Nőgyógyászati Szövetség (Federation International of Gynecology and Obstetrics); HAPO: Hyperglycaemia and Adverse Pregnancy Outcomes; IADPSG: Diabéteszes Terhességgel Foglalkozó Munkacsoportok Nemzetközi Szövetsége (International Association of Diabetes and Pregnancy Study Groups); LGA: terhességi korhoz viszonyítva nagy súlyú magzat (large for gestational age); NICE: Brit Nemzeti Egészségügyi Intézet (National Institute of Health and Care Excellence); NPH: neutrális protamin Hagedorn, intermedier hatású inzulin 
$\Lambda$ diabetes és terhesség társulásának leggyakoribb megjelenési formája a GDM, amely a terhességgel szövődött cukoranyagcsere-zavarok $80-90 \%$-áért felelős. E kórállapot gyakorisága az elmúlt évtizedekben kifejezetten emelkedett, hazánkban 1997 és 2006 között mintegy háromszorosára nőtt. ${ }^{1}$ A felismeretlen GDM mind aktuálisan, mind hosszú távon kedvezőtlen következményekkel járhat. Anyai oldalról gyakoribbá válhat a hypertonia-preeclampsia, a koraszülés, a szülési trauma és a császármetszés előfordulása, magzati vonatkozásban nőhet az LGA-k világrajövetele, az újszülöttkori hypoglykaemia és a respiratorikus distress szindróma kialakulása.

GDM után jelentősen megnő az anyai cardiovascularis rizikó és a diabetes megjelenésének valószínűsége. GDM-es anyák gyermekeiben gyakoribb a fiatalkori elhízás, a csökkent glukóztolerancia és a manifeszt diabetes megjelenése. E kedvezőtlen elváltozások kialakulásának két legalapvetőbb tényezője az elhízás és a hyperglykaemia. Mind a túlsúly, mind az emelkedett vércukorszint önmagában is jelentősen növeli a preeclampsia, a macrosomia és a császármetszések prevalenciáját, a kettő társulása azonban a gyakoriságot tovább növeli. ${ }^{2}$

E riasztó tendencia megállításának módozatai között említhető a GDM kialakulásának csökkentése/esetleges megelőzése, mielőbbi felismerése, optimális kezelése és a veszélyeztetettek utánkövetése. Munkánk e lehetőségeket tekinti át.

\section{Megelözhetö-e a GDM?}

A kérdés megválaszolásához először is át kell tekintenünk a GDM legjelentősebb kockázati tényezőit. ${ }^{3}$ Ilyen a cukorbetegség előfordulása az első fokú rokonok között, a terhelő szülészeti anamnézis (halva-, koraszülés, méhen belüli elhalás, fejlődési rendellenességgel világra hozott gyermek, $>4000$ grammos magzat világrahozatala), az ikerterhesség és az asszisztált reprodukcióval fogant graviditas. Idesorolható a korábbi - akár átmeneti - szénhidrátanyagcsere-zavar (pl. IFG, IGT, GDM), a magasabb anyai életkor (>35 év), a dohányzás és a túlsúly/elhízás $\left(\mathrm{BMI}>27,0 \mathrm{~kg} / \mathrm{m}^{2}\right)$. Ezek közül igazán csak az utolsó kettő a valóban módosítható tényező.
A következő megvizsgálandó kérdés, hogy egészséges nők esetében az életmódváltás biztosan kockázatcsökkenést eredményez-e.

Erre kerestek választ amerikai szerzők közel 15000 egészséges nő bevonásával. Esetükben prekoncepcionális edukációval és a változtatás iránti motiváció felkeltésével életmódváltást értek el a dohányzás elhagyása, valamint heti $\geq 150$ perc fizikai aktivitás és tervezetten egészséges táplálkozás bevezetésével, illetve folyamatos fenntartásával. Azt tapasztalták, hogy e változtatások a GDM kockázatának >40\%-os csökkenését eredményezték. ${ }^{4}$ Más szerzők azt is megfigyelték, hogy a rendszeres fizikai aktivitás önmagában is mintegy 30\%-os kockázatcsökkenést eredményez. ${ }^{5}$ Az egyes személyek konkrét kockázatcsökkenése annál kifejezettebb, minél több rizikót csökkentő életmódtényező valósul meg egyidejüleg. ${ }^{4}$

Vizsgálták azt is, hogy hasonló kockázatcsökkenés magas GDM-veszélyeztetettségű nők körében is elérhető-e.

Egy finn vizsgálócsoport 293 GDM-en átesett vagy elhízott $\left(\mathrm{BMI}>30,0 \mathrm{~kg} / \mathrm{m}^{2}\right)$ asszonyt követett újabb várandóssága 20. hetétől a graviditas befejeződéséig. A random besorolással intervenciós csoportba kerülők $(n=155)$ személyre szabott mozgásprogramot folytattak és szoros testsúlykontrollt biztosító étrendet követtek. A másik csoportban $(n=138)$ a szokásos ellenőrzést, étrendet és fizikai aktivitást alkalmazták. Azt találták, hogy az intervenciós csoportban a GDM incidenciája és a testsúlynövekedés is szignifikánsan alacsonyabb volt a kontrollokéhoz képest. Megállapították, hogy a magas GDM-kockázatú terhes nők GDM-incidenciáját az intenzív életmódkezelés 39\%-kal csökkenti. ${ }^{6}$

Új keletű megfigyelés, hogy az alvás minősége is befolyásolja a GDM kockázatát: a ,jó éjszakai alvással” a GDM megelőzhető. A szerzők vizsgálata szerint mind az átlagosnál hosszabb, mind az átlagosnál rövidebb tartamú alvás kockázatfokozó hatású, legkedvezőbbnek a 7-8 óra közötti időszakot találták. ${ }^{7}$

\section{A GDM kórismézése}

A fent összefoglaltakból következik, hogy a terhesség alatti szénhidrátanyagcsere-zavarok időben történő felismerése alapvető jelentőségü. A GDM szűrésére Európában 2014-ig a WHO 
1999-es módszertani útmutatásában leírt 75 grammos OGTT volt a legáltalánosabban használt diagnosztikus eljárás, ${ }^{8}$ amit a WHO/IDF konzultáció 2006-ban - az éhomi vércukorszint értékhatárát 6,0 mmol/l-re módosítva - lényegében megerősített. ${ }^{9}$ A diabetes terhesség alatti diagnosztikája új irányt vett a Hyperglycaemia and Adverse Pregnancy Outcomes (HAPO) vizsgálat adatainak napvilágra kerülését követően.

E vizsgálatban több mint 20000 várandósság adatai szerepeltek. A 75 grammos OGTT értékeit és a terhességek kimeneteli mutatóit összevetve azt találták, hogy a korábbi kritériumok alapján a GDM-es esetek egy része felismeretlen marad. ${ }^{10}$ E tanulmány nyomán az IADPSG új kórismézési rendszert ajánlott. Eszerint terhességi cukorbetegségről akkor beszélhetünk, ha a 75 grammos OGTT idején mért éhomi vércukor - vénás plazmából laboratóriumi módszerrel mérve $-\geq 5,1$, a 60 perces érték $\geq 10,0$, a 120 perces pedig $\geq 8,5$ $\mathrm{mmol} / \mathrm{l}$. A három érték bármelyikének kóros volta elegendő a GDM diagnózisának felállításához. ${ }^{11}$ E munkacsoport különválasztotta a várandósság alatt felismert manifeszt diabetes kórismézési feltételeit, amelyek megegyeznek a nem-terhes állapotban is alkalmazottakkal. A manifeszt diabetes diagnózisának alternatív lehetőségeként elfogadta a $>6,5 \%$-os $\mathrm{HbA}_{1 \mathrm{c}}$-értéket is. ${ }^{11}$

Új diagnosztikus kritériumok szükségességét a nemzetközi szakmai testületek többségükben elismerték, és sorra újították meg a terhességi szénhidrátanyagcsere-állapot értékelésével kapcsolatos állásfoglalásaikat. Egy részük változtatás nélkül átvette az IADPSG értékhatárait. Közéjük tartozott a WHO, ${ }^{12}$ az EBCOG,${ }^{13}$ valamint az ADA. ${ }^{14}$ Más szakértői testületek, elfogadva a megújulás szükségességét, eltérő értékelési rendszert dolgoztak ki. Ezek sorába tartozik a NICE, amely az éhomi vércukor terhességben még elfogadott értékét $<5,6$, az OGTT 2 órás értékét pedig $<7,8 \mathrm{mmol} / \mathrm{l}$-ben állapította meg, egyben elvetette három terhelési érték vizsgálatát. Az éhomi vércukor normális értékét klinikai megfigyelések és gazdasági megfontolások figyelembevételével határozta meg. ${ }^{15}$ A FIGO támogatta az IADPSG diagnosztikus rendszerét, de azt tanácsolta, hogy minden ország saját maga döntsön a választandó, a helyi sajátosságoknak és az egészségügyi rendszer tehervállaló képességének leginkább megfelelő eljárásról. ${ }^{16}$ Az ACOG későbbi, nagy esetszámú, randomizált vizsgálat eredményeitől tette függővé diagnosztikus előírásainak esetleges megváltoztatását. ${ }^{17}$ Az MDT Diabétesszel Társuló Terhességgel Foglalkozó (röviden: terhes-diabetológiai) Munkacsoportja szakértői interdiszciplináris megbeszélést követően a NICE álláspontját fogadta el azzal a kikötéssel, hogy egy-két éves tapasztalatok birtokában ismét napirendre tűzi a kérdést. ${ }^{18}$

A hazai álláspont kialakításakor számos szempontot kellett figyelembe vennünk. Egyrészt azt, hogy - igazodva a nemzetközi állásfoglalásokhoz ${ }^{12}$ - különbséget tegyünk-e a manifeszt - azaz a várandósság idején felismert sui generis - diabetes, illetve a terhesség alatt kialakuló hyperglykaemiás állapot között (ez utóbbi olyan anyagcserezavart jelöl, amelynek vércukorértékei nem érik el a nem-terhes állapotban diabetesnek minősülő mértéket). Másrészt azt, hogy figyelembe véve a graviditas idején fiziológiásan csökkenő éhomi vércukorszintet, mit tekintsünk a még normális éhomi vércukor felső határának. Harmadrészt, hogy hány pontos OGTT-t javasoljunk és figyelembe vegyük-e a $\mathrm{HbA}_{1 \mathrm{c}}$-értéket, végül, hogy olyan diagnosztikus rendszert javasoljunk, amely a hazai egészséggazdasági feltételekkel is összhangba hozható.

Úgy ítéltük meg, hogy a kezelés várható intenzitása tekintetében nem mindegy, hogy már kialakult cukorbetegség áll-e fenn, avagy feltehetően enyhébb glukózanyagcsere-zavarról van szó. $\mathrm{Az}$ előbbi ugyanis az esetek jelentős részében a terhesség alatt inzulinkezelést tesz szükségessé, továbbá jóval nagyobb a diabetes véglegessé válásának kockázata. ${ }^{19}$

Utánvizsgálatok eredményeként nyilvánvaló vált, hogy az IADPSG-kritériumok alapján kórismézett GDM-es esetek gyakorisága a klasszikus WHO-értékelés szerint felismert esetekének több mint kétszerese, és ennek hátterében döntő mértékben a még normálisnak tekintett éhomi vércukorszint leszállítása állhat. ${ }^{20,21}$ Több vizsgálat, közöttünk saját megfigyeléseink ${ }^{22}$ is azt igazolták, hogy az IADPSG szerinti három értékelési pont közül a legkisebb a 60 perces érték diagnosztikus jelentősége, ugyanakkor a háromszori vérvétel jelentősebb megterhelést okoz mind a vizsgált személyek, mind a laboratóriumi személyzet számára. A $\mathrm{HbA}_{1 \mathrm{c}}$ diabetest kórjelző értékét legutóbbi állásfoglalásában a WHO is elfogadta. ${ }^{21}$ Terhességben azonban, ahol élettanilag haemodilutio alakul ki, alkalmazásával nem áll rendelkezésre kellően nagy tapasztalat, továbbá ismert, hogy a nem-terhes állapothoz képest a $\mathrm{HbA}_{1 \mathrm{c}}$ értéke is csökken. ${ }^{23}$ (Egy 
megfigyelés szerint már a koraterhességi 5,9-6,6\%os $\mathrm{HbA}_{1 \mathrm{c}}$-szint is magzati kockázatot jelenthet. ${ }^{24}$ ) A felsorolt tényeket mérlegelve a $\mathrm{HbA}_{1 \mathrm{c}}$ a diabetes terhességi kórismézéséhez nem került be a hazai ajánlásba.

Röviden ki kell térnünk egy gyakran felvetett kérdésre: a GDM-esetek számának növekedése a diagnosztikus kritériumok változásának a következménye-e, avagy abban más tényezők is közrejátszanak? Nos kétségtelen, hogy - amint arra már kitértünk - az értékelés módosulása jelentősen növelte az előfordulás gyakoriságát, a teljességhez tartozik azonban, hogy már a kórismézési gyakorlat módosulása előtt is a prevalencia kifejezett emelkedése volt megfigyelhető.

A fentiek figyelembevételével az MDT Diabéteszszel Társuló Terhességgel Foglalkozó Munkacsoportja interdiszciplináris szakértői megbeszélés eredményeként - az MDT vezetőségével egyetértésben - a GDM kórismézése vonatkozásában a következő ajánlásokat tette: ${ }^{18}$

1. Teljes körű terhességi diabetes szűrés szükséges minden várandós nő esetében;

2. Koraterhességben (a terhesség első 12 hetében), a várandós első laboratóriumi vizsgálata során a manifeszt diabetes szűrése a feladat. Terhesség alatt manifesztálódó diabetes kórismézhető, ha vénás plazmában, laboratóriumi meghatározással az éhomi vércukor $\geq 7,0 \mathrm{mmol} / 1$ és/vagy a random vércukor $\geq 11,1 \mathrm{mmol} / \mathrm{l}$;

3. GDM szempontjából nagy kockázatú személyeken (1. táblázat) manifeszt diabetes kizárása után a 16-18. terhességi hét között 75 grammos OGTT végzése indokolt a gestatiós

1. táblázat. Gestatiós diabetes tekintetében fokozottan veszélyeztetett asszonyok

\footnotetext{
- Életkora $<18$, illetve $>35$ év

- Túlsúlyos / elhízott (BMI >27 kg/m²)

- A metabolikus szindróma jegyeit hordozza

- Első fokú rokonai között több cukorbeteg fordul eló

- Kórelőzményében korábbi szénhidrátanyagcsere-zavar szerepel

- Ikerterhességet hordoz

- Várandóssága asszisztált reprodukcióval következett be

- Terhelő szülészeti anamnézisűek (halva-, koraszülés, méhen belüli elhalás, eclampsia, fejlődési rendellenességgel született gyermek, terhességi korra számított nagy magzat világrahozatala)
}

hyperglykaemia felismerésére, az alábbi, 4. pontban felsorolt értékelési szempontokkal. Amennyiben ezen OGTT negatív eredményű, a terhelés a 24-28. terhességi hét között megismétlendő;

4. A terhesség 24-28. hetében 75 grammos OGTT végzése indokolt (amennyiben a terhesség korábbi szakaszában glukózanyagcsere-zavar nem volt igazolható). Gestatiós hyperglykaemia áll fenn, ha a vénás plazmában az éhomi vércukor $\geq 5,6 \mathrm{mmol} / \mathrm{l}$ és/vagy a kétórás érték $\geq 7,8 \mathrm{mmol} / 1$. A cukoroldat elfogyasztása előtt ujjbegyes tájékozódó éhomi vércukorvizsgálat javasolt a diabetes kizárására;

5. Rizikócsoportba tartozóknál a 4. pontban felsoroltak szerint negatív OGTT esetén egyéni mérlegelés alapján a terhesség 30-32. hetében a cukorterhelés újra elvégzendő lehet.

Az új állásfoglalás tehát különbséget tesz a koraterhességi manifeszt diabetes, illetve a terhesség alatt jelentkező gestatiós hyperglykaemia között, bár ez utóbbit is gestatiós diabetesként tartjuk számon. Lényeges különbség a korábbi értékeléssel szemben az is, hogy várandósság idején az $5,6 \mathrm{mmol} / 1$ éhomi vércukorszintet elérő értéket már kórosnak, egyben diagnosztikus értékủnek tekintjük.

A graviditas során felismert bármely típusú glukózanyagcsere-zavar intenzív interdiszciplináris diabetológiai szakellátást igényel. A szülést követően az anyagcsere-állapot reklasszifikációja szükséges.

\section{Vércukorcsökkentő kezelés gestatiós diabetesben}

A kezelés legfőbb célkitűzése az, hogy a terhesség kimenetele mind az anya, mind a magzat számára a lehető legkedvezőbb legyen. E vonatkozásban általánosságban elmondható, hogy alapvető cél az anyagcserezavarban nem szenvedő várandósokra jellemző normoglykaemiás anyagcserehelyzet megvalósítása, továbbá a túlzott súlygyarapodás megelőzése. Fontos szempont a kezelés ellenőrzése is, amely rendszeres egy-kéthetenkénti klinikai kontrollt, valamint laboratóriumi (vércukor, vizeletcukor, aceton, fruktózamin) vizsgálatokat jelent. Indokolt a vércukorszint gyakori önellenőrzése is 
előre egyeztetett szempontok alapján, amely inzulinkezelés esetén naponta 6-12 meghatározást foglalhat magában.

Alapvető kérdés, hogy melyek legyenek a glykaemiás kontroll célértékei a GDM gondozása során. Előre kell bocsátanunk, hogy e tekintetben az ADA hatályos ajánlása ${ }^{25}$ és az európai - azzal egyezően a hazai - gyakorlat különbözik egymástól. Ennek az a magyarázata, hogy az anyai glykaemiás kontroll különböző tudományos szervezetek által ajánlott célértékei csupán konszenzusos álláspontokon és nem magas szintű evidenciákon alapulnak. ${ }^{26} \mathrm{Az}$ ADA legutóbbi irányelve szerint az éhomi vércukor terhességben követendő célértéke ne haladja meg az 5,3, az étkezés után 1 órával mért a 7,8, az étkezés után 2 órával mért a 6,7 $\mathrm{mmol} / \mathrm{l}-\mathrm{t}^{25} \mathrm{~A}$ hazai állásfoglalás - egybehangzóan más irodalmi adatokkal ${ }^{27,28}$ - a preprandialis vércukor célértékét 3,5-5,4, az étkezés után 1 órával mértet $\leq 7,0$, az étkezés után 2 órával mért értéket $\leq 6,1 \mathrm{mmol} / \mathrm{l}$-ben határozta $\mathrm{meg} .{ }^{29}$

A GDM vércukorcsökkentő kezelésének két alappillére az életmódkezelés és az inzulinadás. Visszatérő kérdésként jelentkezik az orális antidiabeticumok várandósság idején történő alkalmazhatósága. Különösen a metformin esetében merül föl adagolásának folytatása a terhesség igazolódását követően is, olyan esetekben, amikor a fogamzás csak hosszas próbálkozások után sikerült, és a gyógyszer adásának célja a graviditas megtartásának támogatása. E véleményekkel szemben több adat is felsorakoztatható. Egyrészről a metformin átjut a placentán és a magzati gyógyszerszint az anyában mértnél magasabb. ${ }^{30,31}$ Másrészről a metformin fokozhatja a koraszülés kockázatát, ${ }^{25}$ nem egyértelműen igazolt a terhesség megmaradását támogató hatása ${ }^{25}$ és hiányoznak az alkalmazása mellett született gyermekekkel kapcsolatos hosszú távú megfigyelések is. Mindezen okokra tekintettel, igazodva e készítmények hatályos törzskönyvi előírásaihoz, metforminadás igazolt terhességben történő folytatását ellenjavalltnak gondoljuk. Hasonló értelemben foglal állást az ADA ez évben megjelent, a gestatiós diabetes kezelésével kapcsolatos ajánlása is. ${ }^{25}$

Az utóbbi időben - e gyógyszercsoport előnyös hatástani sajátosságai ismeretében - előtérbe került az inkretintengelyen ható készítmények PCOS-ben történő alkalmazásának lehetősége, metforminnal vagy pioglitazonnal együtt, esetleg hármas kombinációban. Adásuk eredményeként mérséklődhet az inzulinrezisztencia, javulhat a béta-sejtműködés és metforminos kombinációban csökkenhet a testsúly. ${ }^{32,33}$ Le kell azonban szögeznünk, hogy e származékok, a dipeptidilpeptidáz-4-gátlók és a glukagonszerű peptid-1 receptor agonisták egyaránt, megfelelő antikoncepció hiányában már a prekoncepcionális időszakban ellenjavalltak, és ellenjavalltak később, a várandósság idején is! Ezt egyébként valamennyi készítmény alkalmazási előirata is ennek megfelelő értelemben tartalmazza.

Az életmódkezelés egyik kulcseleme a személyre szabott étrend - az érintett személlyel egyeztetett kialakításban. Célja, hogy a megfelelő tápanyag- és energiabevitel mellett biztosítsa az anya euglykaemiás állapotát és a felesleges súlygyarapodás elkerülését. Mindig szakavatott dietetikus bevonásával kell megtervezni és a kismamával megtaníttatni, teljesülését pedig a kontrollvizsgálatok során, szükség esetén diétás napló segítségével kell ellenőrizni.

A GDM étrendi kezelésével kapcsolatban ma nincs egységes, általánosan elfogadott ajánlás, a legtöbb szakértői vélemény azonban egyetért a cukormentes, alacsonyabb szénhidrát- (általában napi 150-170 gramm) tartalmú, alacsony glykaemiás indexü és - túlsúly fennállása esetén - energiatartalmában megszorított (napi 1400-1800 kcal), napi több alkalomra elosztott táplálékbevitel szükségességével. ${ }^{34,35}$ Tekintettel a GDMben jelentős pp. vércukor-emelkedési hajlamra - ami a reggeli órákban a legkifejezettebb -, tanácsos a reggeli szénhidráttartalmának relatív csökkentése és a tízórai szénhidrátbevitelének növelése. Gyakorlatunkban e két étkezés szénhidráttartalma közel azonos, sőt a tízórai szénhidrátbevitel a reggelinél még nagyobb is lehet. A gyorsan felszívódó szénhidrátok, pl. a tej reggelihez történő fogyasztása kerülendő, a kívánt mennyiség inkább tízóraira vagy uzsonnára kerüljön át.

A GDM életmódkezelésének másik fontos tényezője a rendszeres testmozgás, ami lehet napi 30 percnyi mérsékelt fizikai aktivitás (pl. intenzívebb séta) vagy 10-10 perces, ülőhelyzetben végzett karemelési gyakorlat a fóétkezések után. ${ }^{21} \mathrm{Az}$ adott esetben tanácsolt mozgásmennyiséget és formát mindig a társszakmák véleményének figyelembevételével kell meghatározni.

Ha az életmódkezelés önmagában nem biztosítja a normoglykaemiát, inzulin kiegészítő adagolása szükséges. A több éve-évtizede forgalmazott inzulinkészítmények döntő többsége - a glulisin, 
a glargin, a degludec, valamint a biohasonló származékok kivételével - a potenciális magzati károsodások szempontjából FDA „B” besorolásúak, ${ }^{21}$ azaz humán kockázat vonatkozásában nincs bizonyíték. Gyakorlatunkban inzulinkezelést kezdünk, ha az étkezés után egy órával mért vércukorérték ismételten $\geq 7,0 \mathrm{mmol} / \mathrm{l}$.

A kívánatosnál nagyobb pp. vércukor-emelkedés a fóétkezések előtt gyors hatású humán inzulin adagolását teszi szükségessé. Így a napi inzulininjekciók száma 1-3 között változhat. Ultragyors hatású inzulinanalógok adagolása várandósság idején az alkalmazásuknál szokásos étkezések esetenként magasabb szénhidráttartalma (és nagyobb volumene) folytán véleményünk szerint nem ideális. A $\geq 5,4 \mathrm{mmol} / 1$ éhomi vércukorérték már - leggyakrabban lefekvéskor adott - bázisinzulin-pótlás bevezetését is szükségessé teszi. Bázisinzulinként elsősorban humán NPH típusú készítmény választása tanácsolható. ${ }^{21}$

A GDM során megkezdett inzulinkezelés a szülést követően az esetek döntő többségében elhagyható, ha csak nem 1-es típusú cukorbetegség manifesztációjáról van szó. A gyermekágyas időszakban a megfelelő étrenddel az anyagcsere-egyensúly az esetek túlnyomó többségében biztosítható, a szoptatás idején a nem-inzulintermészetű vércukorcsökkentő készítmények alkalmazása egyébként is ellenjavallt.

\section{A GDM utánkövetése}

A GDM-es anyák és gyermekeik további követéséről a közelmúltban interdiszciplináris szakértői állásfoglalás jelent meg. ${ }^{18} \mathrm{~A}$ részletek tekintetében utalunk az abban foglaltakra.

Az utóbbi időben mind gyakrabban tapasztaljuk, hogy az orvosi figyelmen kívül esik az az állásfoglalás, miszerint a sui generis GDM egy asszony életében csak egyszer kórismézhető. Rendezett szénhidrát-anyagcsere esetén is egy következő terhesség tekintetében pregestatiós cukorbetegnek tekintendő, azaz a szakma szabályai szerint prekoncepcionális gondozásban kell részesíteni. Várandósság hiányában is rendszeres anyagcsere-ellenőrzése szükséges.

Graviditas ismételt bekövetkezésekor azzal a dilemmával kerülünk szembe, hogy - addig rendezett szénhidrát-anyagcsere mellett is - végeztessünk-e OGTT-t már az első trimeszterben, vagy sem. Igen valószínű, hogy az eredménytől függetlenül a terápiás terv ugyanaz lesz - hiszen inzulinadagolás indítását vagy az önmagában alkalmazott életmódkezelés fenntarthatóságát végső soron a rendszeres vércukormérések eredménye határozza meg -, az ellenőrzés intenzitását és a javasolt étrend betartásának ellenőrzését azonban meghatározza az anyagcsere állapotának pontos ismerete.

Ugyanez a helyzet 2-es típusú diabeteses aszszonyok várandóssága esetén. $\mathrm{Ha} \mathrm{pl}$. a teherbeesés előtt - szándékolt fogyókúra eredményeként - jelentősebben csökken a testsúlya, vagy a korábbihoz képest rendszeresen intenzívebb fizikai tevékenységet végez, s ezek eredményeként az aktuális laboratóriumi leletek (éhomi és pp. vércukor, fruktózamin, $\mathrm{HbA}_{1 \mathrm{c}}$ ) alapján manifeszt diabetes kizárható, kérdéses, hogy élettani stressz - pl. újabb terhesség - eredményeként anyagcseréje normoglykaemiás marad-e, vagy sem. Ennek eldöntése csak OGTT-vel lehetséges. Ezen gondolatmenet alapján a korábban GDM-es, ismét várandós kismamák esetében is szükségesnek gondoljuk a koraterhességi cukorterheléses vizsgálatot.

A korábban GDM-es anyák és gyermekeik hoszszú távú követése tanácsolható, kiemelt hangsúlylyal az egészséges életmód, a normális tápláltsági állapot és az életmódba épített, legalább heti ötszöri, alkalmanként 30 percig vagy kiizzadásig folytatott, a teherbíró képességhez igazított fizikai aktivitás hangsúlyozására és a legalább évente elvégzett glukózanyagcsere-vizsgálat megtörténtének ellenőrzésére. Így esély nyílik az anyagcserezavar minél korábbi felismerésére, a hátterében álló oki tényezők esetleges feltárására és a hatékony kezelés elkezdésére.

Közlésre érkezett: 2017. november 27.

Közlésre elfogadva: 2018. január 18.

A levelezésért felelős szerző:

Dr. Baranyi Éva

Magyar Honvédség Egészségügyi Központ, 1-es telephely, Diabetológiai Szakrendelés

1134 Budapest, Róbert Károly krt. 44.

E-mail: timar.baranyi@gmail.com 


\section{rrodalom}

1. Zsirai L, Csảkány MGy, Tabák Gy, Egyed J, Török M, Vargha P, et al.: Emelkedó pregesztációs és gesztációs diabétesz incidencia Magyarországon: Az Országos Szülészeti és Nógyógyászati Intézet 1997-2006. közötti adatbázisának validálása és elemzése. Diabetol Hung 2011; 19(2): 125-134.

2. Hilden A, Hanson U, Persson M, Fadl A: Overweight and obesity: a remaining problem in women treated for severe gestational diabetes. Diabetic Med 2016; 33(8): 1045-1051. doi:10.1111/dme.13156

3. Zhang C, Rawal S, Chong YS: Risk factors for gestational diabetes: is prevention possible? Diabetologia 2016; 59(7): 1385-1390. doi:10.1007/s00125-016-3979-3

4. Zhang C, Tobias DK, Chavarro JE: Adherence to healthy lifestyle and risk of gestational diabetes mellitus: prospective cohort study. British Med J 2014; 349: g5450. doi:10.1136/bmj.g5450.

5. Sanabria-Martinez G, Garcia-Hermoso A, Poyatos-León R, Alvarez-Bueno C, Sanchez-Lopez M, Martinez-Viscaino V: Effectiveness of physical activity interventions on preventing gestational diabetes mellitus and excessive maternal weight gain: a meta-analysis. BJOG 2015; 122(9): 1167-1174. doi:10.1111/1471-0528.13429

6. Koivusalo SB, Rono K, Clemetti MM, Roine RP, Lindström J, Erkkola M, et al.: Gestational diabetes mellitus can be prevented by lifestyle intervention: the Finnish Gestational Diabetes Prevention Study (RADIEL) - a randomized controlled trial. Diabetes Care 2016; 39(1):24-30. doi:10.2337/dc15-0511

7. Wang J, Leng W, Li L, Wang C, Zhang W, Li H, et al.: Sleep duration and quality, and risk of gestational diabetes mellitus in pregnant Chinese women. Diabetic Med 2017; 34(1): 44-50. doi:10.1111/dme.13155

8. WHO: Definition, diagnosis and classification of diabetes mellitus and its complications. Report of a WHO consultation. Part I: Diagnosis and classification of diabetes mellitus. WHO, Geneva, 1999.

9. Report of a WHO/LFF consultation: Definition and diagnosis of diabetes mellitus and intermediate hyperglycaemia. WHO, Geneva, 2006. http://www. idforg/webdata/docs/who_IDF_definition_diagnosis_of_diabetes.pdf

10. The HAPO Study Cooperative Research Group: Hyperglycaemia and Adverse Pregnancy Outcomes. New Engl J Med 2008; 358(19): 1991-2002.

11. International Association of Diabetes and Pregnancy Study Groups Consensus Panel (IADPSG): International Association of Diabetes and Pregnancy Study Groups recommendations on diagnosis and classification of hyperglycemia in pregnancy. Diabetes Care 2010; 33(3): 676-682. doi:10.2337/dc09-1848

12. WHO: Diagnostic criteria and classification of hyperglycaemia first diagnosed in pregnancy. WHO, Geneva, 2013. http://www.who.int/iris/ bitstream/10665/85975/who_NMH_MND_13.2

13. Benhalima KI, Mathieu C, Damm P, Van Assche A, Devlieger R, Desoye G, et al: A proposal for the use of uniformed diagnostic criteria for gestational diabetes in Europe: an opinion paper by the European Board and College of Obstetrics and Gynecology (EBCOG). Diabetologia 2015; 58(7): 1422-1429. [erratum: Diabetologia 2016; 59 (8):pp. 1791.] doi:10.1007/s00125-015-3615-7

14. American Diabetes Association: Standards of medical care in diabetes 2014. Diabetes Care 2014; 37(Suppl. 1): S14-S80, doi:10.2337/dc14-S014

15. National Collaborating Center for Women and Children Health: Diabetes in pregnancy: management of diabetes and its complications from preconception to the postnatal period. http://nice.org.uk/guidance/ng3

16. The International Federation of Gynecology and Obstetrics (FIGO): Iniciative of gestational diabetes mellitus: a pragmatic guide for diagnosis, management and care. Intern J Gynecol Obstet 2015; 131(Suppl. 3): S173-S211. doi:10.1016/50020-7292(15)30007-2

17. American College of Obstetricians and Gynecologists: Gestational diabetes mellitus. Practice Bulletin № 137. Obstet Gynecol 2013; $122(2$ Pt 1): 406-416. doi:10.1097/01.A0G.0000433006.09219.f1
18. A Magyar Diabetes Társaság (MDT) Diabétesszel Társuló Terhességgel Foglalkozó Munkacsoportja 2015. október 6-i kerekasztal-megbeszélésének ajánlásai (szerk: Baranyi É, Winkler G): Javaslat a terhesség alatti glukózanyagcsere-zavarok felismerésére. Diabetol Hung 2016; 24(2): 85-88.

19. Rayanagoudar G, Hashi AA, Zamora J, Khan KS, Hitman GA, Thangaratinam S: Quantification of the type 2 diabetes risk in women with gestational diabetes: a systematic review and meta-analysis of 95,750 women. Diabetologia 2016; 59(7): 1403-1411. doi:10.1007/s00125-016-3927-2

20. Kun A, Tabák Gy A, Sudár Zs, Tornóczky J, Varhga P, Kerényi Zs, et al.: Teljeskörủ GDM-szúrés értékelése a WHO és az IADPSG kritériumrendszere alapján. Diabetol Hung 2014; 22(3): 201-206.

21. ADA: Clinical Practice Recommendations 2016. Diabetes Care 2016; 39(Suppl. 1): $513-522$.

22. Ferenczné Salamon M, Soós Zs, Oláh R, Hazai M, Sóvágó L, Kovács D, et al: A gestatiós diabetes szúrésére ajánlott két nemzetközi eljárás hatékonyságának összehasonlitása. Orv Hetil 2013; 154(20): 776-783.

23. Nielsen RL, Ekbom P, Damm P, Glumer C, Frandsen MM, et al.: HbA $A_{1 c}$ levels are significantly lower in early and late pregnancy. Diabetes Care 2004; 27(5): 1200-1201. doi:10.2337/diacare.27.5.1200

24. Rowan JA, Budden A, Ivanova V, Hughes RC, Sadler LC: Women with an $\mathrm{HbA}_{1 \mathrm{c}}$ of $41-49 \mathrm{mmol} / \mathrm{mol}(5,9-6,6 \%)$ : a higher risk subgroup that may benefit from early pregnancy intervention. Diabetic Med 2016; 33(1): 25-31. doi:10.1111/dme. 12812

25. ADA: Standards of medial care in diabetes. Diabetes Care 2017; 40(Suppl. 1): S114-S119.

26. Martis R, Brown J, Alsweiler J, Crawford TJ, Crowther CA: Different intensities of glycaemic control for women with gestational diabetes mellitus. Cochrane Database Syst Rev; 2016(4): CD011624. doi:10.1002/14651858.CD011624.pub2

27. Hernandez TL, Friedman JE, Van Pelt RE, Barbour LA: Patterns of glycemia in normal pregnancy: should the current therapeutic targets be challenged? Diabetes Care 2011; 34(7): 1660-1668. doi:10.2337/dc11-0241

28. Combs CA, Moses R: Aiming at new targets to achieve mormoglycemia during pregnancy (editorial). Diabetes Care 2011; 34(10): 2331-2332. doi:10.2337/dc11-1411

29. Winkler G: Diabetes és terhesség (in: Jermendy Gy Iszerk.I: A diabetes mellitus kórismézése, a cukorbetegek kezelése és gondozása a felnóttkorban A Magyar Diabetes Társaság szakmai irányelve, 2014.) Diabetol Hung 2014; 22.(Suppl. 1.): $71-75$.

30. Vanky E, Zachlsen K, Spikset 0, Carlsen SM: Placental passage of metformin in women with polycystic ovary syndrome. Fertil Steril 2005; 83(5): 1575-1578. doi:10.1016/j.fertnstert.2004.11.051

31. Charles B, Norris R, Xiao X, Hague W: Population pharmacokinetics of metformin in late pregnancy. Ther Drug Monit 2006; 28(1): 67-72. doi:10.1097/01.ftd.0000184161.52573.0e

32. El-Halwagy AS, Al-Gergawy AA, Eleslam ES, Abd Elbar ES: Clinical and biochemical changes in polycystic ovarian syndrome patients in response to 3 different oral hypoglycemic drugs: a double-blind, randonized, controlled study. Open J Obstet Gynecol 2017; 7: 117-128. doi:10.4236/0jog.2017.71013

33. Yang $Q$, Wang $F$ : Successful pregnancy after improving insulin resistance with the glucagon-like peptide-1 analogue in a woman with polycystic ovary syndrome: a case report and review of literature. Gynecol Obstet Invest 2016; 81(5): 477-480. doi:10.1159/000446951

34. Hans S, Middleton P, Shepherd E, Van Ryswik E, Crowther CA: Different types of dietary advice for women with gestational diabetes Cochrane Database Syst Rev 2017. Feb 25; 2. doi:10.1002/14651858.CD009275.pub3

35. Moses RG. Cefalu WT: Considerations in the management of gestational diabetes mellitus: "you are what your mother ate!" Diabetes Care 2016; 39(1): 13-15. doi:10.2337/dci15-0030 